\title{
INOVASI BIROKRASI DAN OPTIMALISASI PELAYANAN PUBLIK: BELAJAR DARI JEMBRANA, BALI
}

\author{
Romanus Ndau Lendong \\ Jurusan Marketing Communication, Fakultas Komunikasi dan Multimedia, \\ Bina Nusantara University, Jln. K.H. Syahdan No 9, Palmerah, Jakarta Barat 11480 \\ romanlendong@yahoo.com
}

\begin{abstract}
Jembrana Regency is placed strategically to keep Bali existence as a building of culture and civilization. Tribe and religious diversity cause Jembrana to be viewed as 'another Bali', that is a more dynamic and compromising Bali. The current Jembrana is now mesmerizing after less than ten years in self renovation. This article will talk about how strategic bureaucratic innovation in optimalization of public service. Free education and health care policy, that are run consistently by Jembrana's municipal government, become its frontliner in reaching Millenium Development Goals (MDGs) target. Prof. Dr. I Gede Winasa, former regent of Jembrana, is the main character behind this success. His background as academician and expanded relations from international fund organizations are his crusial ammunition to actualize his obsession absolving Jembrana from poverty, stupidity, and backwardness. Among what happens to this country, Jembrana's breakthrough is worthy to be adopted in other areas in this country.
\end{abstract}

Keywords: Jembrana, innovation, bureaucratic, MDG, Winasa, Makepung

\begin{abstract}
ABSTRAK
Kabupaten Jembrana menempati posisi yang strategis dalam menjaga keberadaan Bali sebagai bangunan budaya dan peradaban. Keberagaman suku dan agama menyebabkan Jembrana ibarat 'Bali lain', yakni sosok Bali yang lebih dinamis dan kompromis. Jembrana kini tampil memukau setelah kurang lebih sepuluh tahun berbenah diri. Tulisan ini hendak mengedepankan betapa strategisnya inovasi birokrasi dalam mengoptimalisasi pelayanan publik. Kebijakan pendidikan dan kesehatan gratis yang dijalankan secara konsisten oleh Pemda Jembrana ternyata menjadi ujung tombak daerah ini dalam mencapai traget Millenium Development Goals (MDG's). Prof. Dr. I Gede Winasa, Bupati Jembrana saat ini merupakan tokoh di balik kisah sukses Negeri Makepung ini. Latar belakangnya sebagai akademisi dan relasi luas dengan lembagalembaga dana internasional menjadi amunisi penting untuk mewujudkan obsesinya membebaskan rakyat Jembrana dari jeratan kemiskinan, kebodohan dan keterbelakangan. Di tengah terpuruknya bangsa ini karena kemiskinan dan kebodohan, apa yang dilakukan pemerintah daerah Jembrana merupakan terobosan yang patut ditiru.
\end{abstract}

Katak kunci: Jembrana, inovasi, birokrasi, MDG, Winasa, Makepung 


\section{PENDAHULUAN}

\section{Sekilas Negeri Makepung}

Kabupaten Jembrana menempati posisi yang strategis dalam menjaga keberadaan Bali sebagai bangunan budaya dan peradaban. Keberagaman suku dan agama menyebabkan Jembrana ibarat 'Bali lain', yakni sosok Bali yang lebih dinamis dan kompromis. Dalam bukunya, Naradha (2003) menuliskan bahwa Bali identik dengan keindahan, kenyamanan dan keharmonisan. Payungnya adalah budaya dan kebiasaan yang bersumber pada agama Hindu. Bali juga identik dengan pariwisata sebagai nafas kehidupan orang Bali. Menghadapi akselerasi perubahan yang berakar pada globalisasi, masyarakat Bali mulai gelisah akan masa depannya. Gerakan Ajeg Bali, yakni mempertahankan identitas Bali yang identik dengan Hindu dan Pariwisata, merupakan antisipasinya. Agama Hindu yang selama ini identik dengan Bali, dianut oleh kurang dari 50 persen penduduk Jembrana. Selebihnya adalah agama Islam, Katolik, Kristen Protestan dan Budha. Tapi keragaman suku dan agama tersebut bukan menjadi soal di daerah ini.

Di tengah meluasnya kritik terhadap birokrasi, Jembrana hadir sebagai antitesisnya. Jembrana dikenal sebagai gudangnya orang miskin di Provinsi Bali, sebagaimana tertulis dalam 'Jembrana dalam Angka 2007/08' yang mencatat bahwa pendapatan Jembrana hingga 2001 sangat rendah, yakni Rp. 2,5 milyar. Daerah yang merupakan inovasi birokrasi ini menjadi rujukan banyak pihak, terutama berkaitan dengan penataan birokrasi sebagai kekuatan inti pelayanan dan pemberdayaan rakyat. Pemerintah pusat dan daerah seakan berlomba untuk belajar dari Jembrana. Anggota DPR/D menjadikan daerah ini sebagai salah satu referensi penting dalam menemukan ide-ide inovatif. Jembrana juga menjadi magnet bagi kaum akademisi untuk melakukan kajian berbagai isu, terutama bagaimana birokrasi menjadi kekuatan perubahan.

Di siang hari, Negara, ibu kota Kabupaten Jembrana, memang tidak banyak bedanya dengan kota Denpasar. Jalan utama di Negeri Makepung ini tampak ramai. Makepung, adalah lomba karapan kerbau, kesenian khas daerah ini. Toko-toko juga mulai maju dan pasar selalu hidup. Bedanya, Kota Negara tampak lebih bersih dan terawat ketimbang Denpasar. Di malam hari, Jembrana tampak sepi karena minimnya objek wisata. Pantai Delod Brawah di ujung barat kota Negara dan Pantai Banyu Biru di ujung timurnya merupakan dua objek wisata daerah ini. Kedua pantai ini selalu sepi, ibarat kota tua yang ditinggalkan penduduknya.

Jembrana kini tampil memukau setelah kurang lebih sepuluh tahun berbenah diri. Tulisan ini hendak mengedepankan betapa strategisnya inovasi birokrasi dalam mengoptimalisasi pelayanan publik. Kebijakan pendidikan dan kesehatan gratis yang dijalankan secara konsisten oleh Pemda Jembrana ternyata menjadi ujung tombak daerah ini dalam mencapai traget Millenium Development Goals (MDG’s). ("Edisi Khusus HUT 112 Kota Negara,” 2007) menuliskan tentang dua dari delapan poin target MDG's adalah pendidikan dan kesehatan. Pemda Jembrana sejak tahun 2001 telah secara konsisten memprioritaskan pendidikan dan kesehatan. Jika target MDG's secara global dicapai tahun 2015, pemda Jembrana bisa menyalibnya, yakni 2010.

\section{Obsesi I Gede Winasa}

Prof. Dr. I Gede Winasa, Bupati Jembrana saat ini merupakan tokoh di balik kisah sukses Negeri Makepung ini. Sebagai putra asli Jembrana, Winasa memahami dengan baik persoalan dan kebutuhan masyarakat setempat. Latar belakangnya sebagai akademisi dan relasi luas dengan lembaga-lembaga dana internasional menjadi amunisi penting untuk mewujudkan obsesinya membebaskan rakyat Jembrana dari jeratan kemiskinan, kebodohan dan keterbelakangan. Berbeda dengan elite politik di beberapa daerah yang skeptik dengan kebijakan otonomi daerah, Winasa dan 
pemda Jembrana justru antusias menyambutnya. Otonomi daerah disambut gembira karena ini adalah momentum politik untuk memberi tempat bagi daerah dalam menentukan nasibnya. Adanya kewenangan untuk mengurus diri sendiri merupakan kerinduan lama. Selama orde baru, kewenangan ini sebatas impian; pemerintah pusat memegang komando, segala hal diatur dan dikendalikan pusat. Daerah tidak boleh memilih jalan sendiri bahkan sekedar berbeda pendapat. Risikonya terlalu mahal karena bisa ditafsirkan sebagai bentuk pembangkangan terhadap pemerintah pusat.

Skeptisme beberapa kalangan terhadap otonomi daerah, memang mudah dimaklumi. Otonomi daerah menuntut juga otonomi finansial. Ini tentu tantangan serius, terutama bagi daerah-daerah yang miskin akan sumber daya alam. Tambahan lagi, lemahnya kemauan baik pemerintah daerah, bisa membuat kebijakan ini ibarat memangsa anaknya sendiri. Alih-alih memajukan dan mensejahterakan daerah, otonomi daerah justru bisa membuat masyarakat kembali terjebak dalam kemiskinan dan ketertinggalan. Bagi Pemda Jembrana, gambaran ini tampak berlebihan. Agung Putrayasa, Asisten I Bupati Jembrana, mengakui hal ini. Meski daerah ini minim akan sumber daya alam, bukan alasan baginya untuk pesimis. Otonomi daerah adalah peluang yang harus dioptimalkan. Semua bergantung pada daerah. Aparat pemerintah dan legislatif perlu menyikapi otonomi dengan semangat baru yang lebih proaktif, inovatif dan mandiri. Tidak relevan lagi mendebatkan otonomi daerah. Menurutnya, ini saatnya pemerintah daerah menunjukkan bukti bahwa mereka mampu membangun diri secara mandiri tanpa perlu bergantung pada pemerintah.

Dalam buku 'Anak Desa Penantang Zaman, Biografi I Gede Winasa' (Da Kansas, 2003), tertuliskan secara jelas pandangan Winasa tentang otonomi daerah. Otonomi daerah dilihat sebagai anugerah, karena pemerintah daerah dan masyarakat bisa secara optimal mewujudkan kebutuhannya. Otonomi juga memberi peluang rakyat untuk lebih aspiratif dan terwakili dalam proses penentuan keputusan di daerah. Rakyat lebih partisipatif dan menjadi subjek perubahan. Pemberlakuan otonomi penuh di level kabupaten, merupakan momentum strategis bagi Winasa. Momentum tersebut harus dikelola secara maksimal sehingga menjadi lebih bermanfaat bagi masyarakat. Otonomi daerah ibarat musim hujan, karena menawarkan peluang yang terbuka, setelah 32 tahun bangsa ini dilanda kemarau panjang yakni kekuasaan terpusat yang dominatif dan represif. Rakyat tidak diikutsertakan dalam penentuan kebijakan karena semuanya dimonopoli oleh pemerintah pusat. Pemerintah daerah tidak mempunyai keleluasaan untuk mengambil kebijakan karena struktur komando yang kaku dan membonsai kreativitas. Sebagai peluang, otonomi daerah hendak dioptimalkan oleh Winasa dan jajaran birokrasinya. Menyadari kondisi birokrasi saat ini, Winasa melihatnya sebagai tantangan. Birokrasi memang telah lama hadir sebagai kekuatan yang merintangi, ketimbang mendorong kemajuan daerah. Tapi, pilihannya tetap dimulai dari membenahi birokrasi.

\section{PEMBAHASAN}

\section{Memberdayakan Mesin Birokrasi}

Winasa melihat bahwa setiap pemerintahan memiliki itikad baik untuk memajukan daerah. Sayangnya, niat baik tersebut seringkali kurang berjalan optimal. Terlalu banyak distorsi dalam birokrasi sehingga berbagai persoalan menumpuk. Jumlah PNS mencapai 3,9 juta penduduk, namun dari jumlah tersebut hanya $60 \%$ yang bisa menjalankan tugas secara profesional. Birokrasi masih saja terperangkap dalam kultur yang selalu mau dilayani dan diutamakan. Implikasinya, pelayanan publik terabaikan.

Pada titik ini, reformasi birokrasi menjadi kebutuhan mendesak. Richard Rose, seperti dikutip Peters (1987), menyatakan bahwa setidaknya ada dua syarat untuk bisa bekerjanya birokrasi, yakni tingginya keahlian atau kompetensi kepemimpinan dalam menjalankan organisasi birokrasi dan prioritas mesti diberikan pada implementasi program demi tercapainya hasil yang optimal. Seakan 
mengafirmasi Rose, Winasa merintis langkah-langkah strategis dalam menghidupkan mesin birokrasi sebagai mesin pelayanan publik. Faktor kepemimpinan yang tegas dan disiplin menjadi kuncinya. Berbagai hambatan diatasi secara perlahan dengan mengedepankan supremasi hukum. Bermodalkan tim kerja yang solid, Winasa melakukan penataan kelembagaan, perekrutan calon PNS dan pejabat yang didasarkan pada kriteria profesional dan implementasi program yang bermuara pada pencapaian hasil secara efektif dan efisien. Perwujudan birokrasi yang profesional tersebut dilakukan melalui beberapa langkah, berdasarkan wawancara dengan DS Putra, Kepala Bidang Media Center Kabupaten Jembrana.

Pertama, pendalaman filosofi pelayanan. Mind-set aparat birokrasi diluruskan dari kultur yang selalu mau didahulukan dan dilayani menjadi kekuatan pelayanan. 'Daulat tuanku' tak relevan lagi, digantikan 'daulat rakyat'. Kedua, rekrutmen pejabat dilakukan secara terbuka dengan mengedepankan aspek kualitas dan profesionalitas. Langkah ini membawa manfaat ganda (1) terakomodasinya tenaga-tenga yang berkualitas yang menjadi unsur dasar profesionalisme; (2) mencegah terjadinya korupsi dalam proses seleksi. Winasa berkeyakinan, proses yang benar akan berujung pada tercapainya hasil yang optimal. Ketiga, khusus untuk posisi-posisi strategis seperti jabatan kepala dinas, pemda menyelenggarakan tender jabatan secara terbuka. Calon yang memenuhi syarat dari kepangkatan kepegawaian bebas berkompetisi dalam tender tersebut. Tender ini dimaksudkan untuk mendorong lahirnya persamaan persepsi, program yang realistis, jelas dan rinci serta target hasil yang terukur. Pejabat yang tidak mampu memenuhi target tersebut tentu saja tidak bisa memperpanjang jabatannya.

Keempat, rasionalisasi peran dan tanggungjawab. Setiap orang harus menjalankan tugas yang jelas, dengan waktu yang terukur dan memiliki target hasil yang jelas. Hal ini menjadi pedoman bagi pemerintah untuk melakukan monitoring sekaligus alat evaluasi terhadap kinerja setiap aparat birokrasi. Kelima, perbaikan kesejahteraan pegawai. Bentuknya adalah pemberian gaji ke-14. Realisasinya adalah setiap perayaan ulang tahun Kota Negara, tanggal 15 Agustus. Tujuannya selain untuk meningkatkan kesejahteraan juga untuk membantu PNS yang anaknya masih sekolah. PNS juga mendapat kesempatan untuk meningkatkan kualitas ilmu pengetahuan. di antaranya dengan memberikan kesempatan untuk melanjutkan pendidikan. Ketentuan ini terutama bagi PNS yang memiliki prestasi akademik yang baik.

\section{Disiplin Aparat dan Keterbukaan Informasi}

Penataan birokrasi secara sistematis merupakan jalan bagi terwujudnya aparat yang berkualitas dan bertanggungjawab. Sediono M.P. Tjondronegoro (2003) menegaskan bawah pegawai yang mengelola birokrasi hendaknya memiliki keahlian (vocation) yang didasari oleh pendidikan dan dimantapkan oleh pengalaman serta faktor kesetiaan (dedication and loyalitiy). Kesetiaan modern bukan pada atasan sebagai perorangan tetapi terhadap peraturan. Dalam melayani publik seorang pegawai atau pejabat tidak boleh pilih kasih tetapi faceless, tidak pandang bulu dan tidak mengutamakan keluarga/kerabat saja. Reformasi birokrasi disertai pemberian insentif bagi PNS membawa hasil nyata berupa meningkatnya kedisiplinan yang berujung pada membaiknya kinerja birokrasi. DS Putra berpandangan bahwa disiplin aparat, salah satu soal yang sering diingatkan Bupati Winasa telah membawa hasil positif. Meski belum ada data yang mmenguatkan hal ini, Putra merasakan bahwa semakin jarang pemda mendapatkan protes dari warga karena lambannya penyelesaian berbagai urusan publik.

Disiplin aparat kian membudaya di Jembrana. Para pegawai masuk dan keluar kantor pada waktunya. Jarang ditemui pegawai yang berkeliaran seperti terjadi di beberapa kota, terutama Jakarta. Berbagai urusan bisa selesai dengan cepat, tanpa perlu menunggu lama. Selain kesigapan aparat, penggunaan teknologi informasi (IT) juga mengakselerasi pelayanan publik. Pemda Jembrana juga telah lama menerapkan sistem keterbukaan informasi, berdasarkan UU No. 14/2008 tentang Keterbukaan Informasi Publik antara lain mengatur 4 jenis informasi publik, yakni informasi yang 
harus diumumkan secara serta merta. Berbagai peraturan seperti prosedur pelayanan publik dibuat secara tertulis. Jenis pelayanan, biaya dan waktu yang dibutuhkan untuk suatu urusan, misalnya perizinan usaha diatur secara jelas. Jadi, masyarakat tidak perlu menunggu lama, misalnya, sekedar untuk mengurus surat izin mendirikan bangunan (IMB). Keterbukaan informasi tersebut memacu aparat untuk lebih bertanggungjawab.

Apa yang terjadi di Jembrana merupakan inti dari birokrasi seperti ditegaskan Weber, yakni untuk mendorong tercapainya efisiensi yang tinggi. Keabsahan birokrasi ditakar dari kemampuannya untuk bekerja secara rasional dan efisien dengan ciri-ciri: spesialisasi pekerjaan, hierarki otoritas, aturan-aturan detail dan hubungan impersonal (Wrong, 2003). Birokrasi yang rasional, adil, efisien, dan profesional merupakan prasyarat bagi pelayanan publik yang berkualitas, mudah murah. Inilah inti dari birokrasi sebagai lembaga pelayanan (non-market institution) bukan market institution yang berorietansi keuntungan.

\section{Prioritas Pelayanan}

Birokrasi diperlukan manakala kepemimpinan tunggal tak lagi mampu memimpin masyarakat yang semakin banyak dan di daerah yang semakin luas. Berbagai urusan pun semakin banyak dan beraneka ragam, yang membutuhkan keahlian tertentu. (Tjondronegoro, 2003) Birokrasi menjadi jantung kemajuan kehidupan suatu bangsa.

Setiyono (1998) merumuskan tiga peran birokrasi dalam negara modern. Pertama, memberikan pelayanan umum yang bersifat rutin kepada masyarakat seperti memberikan perijinan, pembuatan dokumen, perlindungan, pemeliharaan fasilitas umum, pemeliharaan kesehatan dan pemeliharaan keamanan masyarakat. Kedua, melakukan pemberdayaan (empowerment) terhadap masyarakat untuk mencapai kemajuan dan kehidupan yang lebih baik; dan ketiga, menyelenggarakan pembangunan (development) di tengah masyarakat seperti pengadaan infrastruktur perhubungan, telekomunikasi, perdagangan, transportasi dan sebagainya.

Peran birokrasi amat strategis sekaligus berat. Keterbatasan sumber daya aparat dan minimnya daya dukung finansial menjadi tantangan tersendiri. Pada titik ini, pemerintah daerah perlu merumuskan kebijakan yang menjadi prioritas demi mencapai target yang jelas disertai indikator yang konkret. Inilah rasionalisasi Pemda Jembrana dalam memberikan prioritas pada pelayanan publik, yakni pelayanan bidang pendidikan dan kesehatan. Prioritas ini juga didasarkan pada pemikiran bahwa kualitas sumber daya manusia merupakan faktor kunci dalam mensukseskan otonomi daerah.

\section{Inovasi Bidang Pendidikan}

Sen (1999) menggarisbawahi bahwa pembangunan adalah proses pembebasan. Pembangunan hendaknya membawa manfaat nyata untuk membebaskan rakyat dari rantai kebodohan, kemiskinan dan keterbelakangan. Baginya, kemiskinan tidak hanya berkaitan dengan kurangnya persediaan cadangan pangan tetapi terutama karena kekurangan demokrasi. Pendidikan, bagi Zen, merupakan salah satu medium pembebasan dimaksud.

Inovasi bidang pendidikan di Jembrana mulai dirintis tahun 2001 meliputi (1) pembebasan biaya sekolah SD-SMU Negeri dan program beasiswa untuk siswa SD-SMU Swasta; (2) pembangunan/perbaikan gedung sekolah; (3) pemberian beasiswa kepada guru untuk melanjutkan pendidikan; (4) peningkatan kesejahteraan guru melalui penambahan insentif tambahan dan (5) penyelenggaraan sekolah kajian. Kelima kebijakan sektor pendidikan ini dilaksanakan secara konsisten disertai upaya evaluasi dan perbaikan terus-menerus. Pembebasan biaya pendidikan diutamakan untuk sekolah negeri, SD-SMU. Sementara untuk sekolah swasta diberikan program beasiswa, terutama bagi siswa yang berprestasi. Kebijakan ini selain untuk membantu siswa juga untuk menciptakan keadilan antara sekolah negeri dan swasta. 
Rendahnya kualitas sumber daya manusia dan rendahnya pendapatan masyarakat merupakan dasar bagi lahirnya kebijakan ini. Mudah dipahami jika kebijakan ini mendapat apresiasi luas dari masyarakat. Pencanangan pendidikan gratis dirasakan sangat membantu masyarakat, terutama kelompok miskin. Putranto, 37 tahun, mengakui hal ini. Pekerjaannya sebagai tukang ojek jelas tidak cukup untuk membiayai pendidikan anak-anaknya. Menurutnya, Bupati Winasa amat baik kepada masyarakat di Jembrana. Kebijakan pendidikan gratis jelas sangat membantu masyarakat; dua orang anaknya bisa sekolah karena tidak perlu membayar. "Tanpa kebijakan pendidikan gratis, anak saya jelas nasibnya sama dengan saya yang tidak berpendidikan sehingga sulit mendapatkan pekerjaan," papar Putranto.

Pengakuan serupa disampaikan Amiek, 40 tahun. Karyawati sebuah perusahaan swasta ini mengaku bahwa anak-anaknya kini bisa sekolah tanpa menyibukkan orang tua. Tanti, anak sulungnya, kini kuliah di Denpasar dan mendapat beasiswa dari pemerintah daerah Jembrana. Anak keduanya, Irvan, kini kelas 3 SMA Negeri Jembrana. Amiek berkeyakinan bahwa kebijakan pendidikan gratis merupakan bentuk dari kepedulian dan kesungguhan pemerintah daerah Jembrana untuk memajukan pendidikan.

Insentif sektor pendidikan Jembrana ini paralel dengan kebijakaan 'Makan Siang untuk Berpikir' di Tamil Nadu, India. Sejak tahun 1970 Negara Bagian Tamil Nadu telah memberikan perhatian serius pada dunia pendidikan. Pemerintah menyiapkan anggaran untuk makan siang gratis bagi siswa. Makan siang gratis ini menjadi pendorong bagi orang tua untuk mengirimkan anaknya ke sekolah. Makan siang ini bahkan diterapkan pada hari libur. Kesuksesan program ini memperlihatkan betapa insentif dapat berjalan dengan baik dalam dunia pendidikan. Pesannya sangat sederhana. Anda tidak bisa belajar jika perut lapar (Rajadhyaksha, 2007).

Kebijakan pendidikan gratis dan beasiswa di Jembrana diperkuat dengan pembangunan gedung dengan pola block grant. Pemerintah menyediakan dana stimulan dalam bentuk bantuan material. Kebijakan serupa pernah diterapkan di Kabupaten Kebumen di bawah kepemimpinan Bupati Hj. Rustriningsih. Inti program ini adalah memberi ruang bagi partisipasi masyarakat dalam membangun pendidikan (Lendong, Prasetyo \& Faisal, 2007). Pelaksanaannya sangat bergantung pada partisipasi masyarakat yang diwadahi oleh komite sekolah. Pola ini membawa manfaat: (1) memnbuka ruang bagi partisipasi masyarakat dalam bidang pendidikan; (2) kualitas gedung sekolah lebih sesuai dengan harapan.

Ditopang dengan tiga kebijakan lain di sektor pendidikan yakni beasiswa dan jaminan kesejahteraan guru dan penyelenggaraan sekolah kajian membuat daerah ini mengalami kemajuan berarti di sektor pendidikan. Partisipasi pendidikan meningkat sehingga anak-anak terbebas dari kewajiban membantu ekonomi keluarga seperti menjadi pengamen, berjualan koran atau pekerja lainnya.

\section{Inovasi Bidang Kesehatan}

Inovasi bidang kesehatan adalah Program 'Jaminan Kesehatan Jembrana” (JKJ). Dasar hukumnya adalah Keputusan Bupati No. 572 tentang Pembentukan Tim Persiapan JKJ. Program yang diluncurkan sejak tahun 2002 ini meliputi rawat jalan tingkat pertama dan penyediaan obat-obatan khusus untuk imunisasi, malaria, TBC, demam derdarah, diare, kusta dan perbaikan gizi.

Ada dua faktor kunci bagi pelaksanaan program ini. Pertama, adanya subsidi dana dari pemerintah daerah untuk memberikan pelayanan kesehatan grtais bagi masyarakat, terutama bagi kelompok miskin. Sebelumnya, subsidi tersebut diberikan kepada Rumah Sakit Umum Daerah. Dengan menunjukkan Kartu JKJ, seseorang bisa mendapatkan pelayanan kesehatan gratis secara cepat dan mudah. Kedua, keterlibatan kelompok masyarakat dalam melaksanakan program ini, sepeerti Puskesmas, Pustu Pembina, RS Swasta, Poliklinik Swasta, Praktek Dokter, Praktek Dokter Gigi dan 
Praktek Bidan di bawah koordinasi JKJ, lembaga asuransi kesehatan yang melekat dengan Dinas Kessehatan. Jadi, program ini tidak dimonopoli oleh pemerintah karena rentan terhadap peluang bagi terjadinya penyimpangan.

Etos kerja dan disiplin aparat merupakan faktor lain kesuksesan program ini. Pelayanan gratis ternyata tidak melemahkan semangat kerja aparat. Pelayanan dilakukan secara cepat dan murah. Semua orang mendapat perlakuan sama, tanpa ada hambatan birokratis sama sekali. JKJ yang semula ditanggapi skeptik oleh beberapa kalangan, kini memperlihatkan hasil yang menggembirakan. Lewat Program JKJ daerah ini mampu untuk menekan angka kematian balita, meingkatkan kualitas kesehatan ibu melahirkan serta memerangi penyakit menular termasuk HIV/AIDS dan penyakit menular lainnya melalui deteksi dini.

Program lain yang menjadi perhatian pemda Jembrana adalah pengembangan ekonomi rakyat, menghidupkan peluang investasi dan pembentukan perusahaan daerah. Didukung oleh pihak swasta, Pemda Jembrana menyulap pantai Delod Brawah yang sebelumnya sepi kini menjadi pusat keramaian, terutama pada hari libur. Lomba Makepung digelar setiap tahun di tempat ini. Pemda juga menyediakan kolam renang dengan bayaran murah, yakni Rp. 1500 bagi anak-anak dan Rp. 3000 untuk orang dewasa tanpa ada pembatasan waktu. Selain itu, pemerintah Jepang mendukung perusahaan air minum Megumi. Program ini mampu memenuhi kebutuhan air minum untuk seluruh kantor pemerintah dan ini merupakan bagian dari efisiensi belanja daerah. Megumi juga mampu menyuplai kebutuhan air minum terutama untuk kebutuhan lokal.

Keberhasilan program pendidikan dan kesehatan yang menunjang program pengembangan ekonomi membuat Pemda Jembrana merasa optimis di masa depan. DS Putra mengakui bahwa obsesi pemerintah daerah adalah mewujudkan Jembrana sebagai daerah yang sehat dan cerdas yang bertumpu pada semangat pelayanan aparat birokrasi. Jika pemenuhan hak pendidikan dan kesehatan di berbagai daerah baru sebatas wacana, Jembrana justru telah melakukannya sejak tahun 2001. Kebijakan subsidi langsung biaya pendidikan atau lebih dikenal dengan kebijakan pembebasan SPP serta didukung dengan peraturan daerah Jembrana tentang wajib belajar 12 tahun, membuat daerah ini seakan tinggal menunggu waktu untuk tercatat sebagai daerah yang telah memenuhi Millenium Development Goals di bidang pendidikan.

\section{PENUTUP}

Jembrana kini hadir sebagai buah bibir karena kemajuan-kemajuan yang dicapai. Inovasi birokrasi dan optimalisasi pelayanan publik, terutama bidang pendidikan dan kesehatan, menjadi primadona dari seluruh cerita mengenai Jembrana. Mudah dipahami, mengapa daerah ini seakan memiliki magnet tersendiri. Apresiasi dan kunjungan berbagai pihak: pemerintah, DPR/D dan akademisi merupakan bentuk dukungan terhadap pencapaian daerah ini. Di tengah terpuruknya bangsa ini karena kemiskinan dan kebodohan, apa yang dilakukan pemerintah daerah Jembrana merupakan terobosan yang patut ditiru. Birokrasi yang tertata baik dan dilandasi oleh semangat pelayanan ternyata mampu membebaskan rakyat dari kemiskinan, kebodohan dan keterbelakangan. Birokrasi hadir sebagai kekuatan pelayanan masyarakat dalam memenuhi kebutuhannya secara optimal. Terpenuhinya akses pendidikan dan kesehatan merupakan kunci untuk mendorong kemajuan daerah sekaligus meleccut kapasitas masyarakat agar bisa berkompetisi dalam percaturan global. Persoalannya, bagaimana memastikan bahwa kebijakan pemerintah daerah akan menjadi permanen? Pertanyaan ini relevan mengingat kelaziman yang terjadi di Indonesia, yakni ganti pemimpin berarti ganti program. Inilah kegelisan masyarakat dan pemda di ujung kepemimpinan Winasa yang akan berakhir 2010 ini. 


\section{DAFTAR PUSTAKA}

Bappeda dan BPS Kabupaten Jembrana (2008) Jembrana Dalam Angka 2007/2008, Jembrana.

Da Kansas, N. (2003). Anak Desa Penantang Zaman: Biografi Prof. Dr. DRG. I Gede Winasa. Bali: Komunitas Kertas Budaya.

Edisi Khusus HUT 112 Kota Negara. (2007). Majalah Ge-Magazine.

Naradha, ABG. S. (2003). Ajeg Bali: Sebuah Cita-Cita. Bali: Pustaka Bali Post.

Peters, B.G. (2001) The Politics of Bureaucracy (5th ed.). London: Routledge.

Rajadhyaksha, N. (2007). The Rise of India, Transformasi dari Kemiskinan Menuju Kemakmuran. Jakarta: Elex Media Komputindo.

Republik Indonesia. (2008) Undang-Undang No. 14 Tahun 2008 tentang Keterbukaan Informasi Publik. Lembaran Negara Republik Indonesia Tahun 2008 Nomor 61. Sekretariat Negara.

Sen, A. (1999) Development as Freedom. Oxford: Oxford University Press.

Setiyono. (2003). Peran Birokrasi dalam Negara Modern. Pusat Penelitian dan Pengembangan Badan Kepegawaian Negara Volume III, No 05.

Tjondronegoro, S.MP. (2003). Sejarah Perumbuhan Birokrasi di Masyarakat. Pusat Penelitian dan Pengembangan Badan Kepegawaian Negara Volume III, No 03.

Wrong, D. (Ed.). (2003). Max Weber Sebuah Khazanah. Yogyakarta: Ikon. 